Syntax Idea: p-ISSN: 2684-6853 e-ISSN: 2684-883X

Vol. 3, No. 8, Agustus 2021

\title{
MENINGKATKAN HASIL BELAJAR EKONOMI MENGGUNAKAN MODEL STAD
}

\section{Irda Putriasari}

SMAN 1 Singkep Singkep District, Lingga Regency Riau Islands Province

Email: irdaptr@gmail.com

\begin{abstract}
Abstrak
Penelitian Tindakan Kelas (PTK) yang berjudul "Meningkatkan Hasil Belajar Ekonomi Menggunakan Model STAD pada Peserta Didik Kelas XII IPS 4 Semester Genap SMA Negeri 1 Singkep Tahun Pelajaran 2019 / 2020” merupakan salah satu usaha untuk meningkatkan mutu pendidikan khususnya peningkatan nilai peserta didik dalam memahami Laporan Keuangan. Hal ini dilakukan karena banyaknya peserta didik yang mengangap akuntansi pelajaran yang sulit, sehingga pada beberapa materi akuntansi jumlah peserta didik yang mencapai Kriteria Ketuntasan Minimum (KKM) masih rendah. Tujuan yang hendak dicapai dari penelitian ini adalah untuk meningkatkan hasil belajar akuntansi peserta didik kelas XII IPS 4 Semester Genap SMA Negeri 1 Singkep dengan menggunakan model STAD. Penelitian ini dilaksanakan di SMA Negeri I Singkep, Kecamatan Singkep Kabupaten Lingga kelas XII IPS 4. Penelitian dilakukan pada semester II tahun ajaran 2019/2020. Rancangan penelitian yang digunakan adalah rancangan penelitian tindakan yang alurnya sebagai berikut: membuat perencanaan tindakan, melaksanakan tindakan dalam pembelajaran, mengadakan pengamatan terhadap pelaksanaan tindakan, dan merefleksi pelaksanaan tindakan. Hasil refleksi tersebut digunakan untuk mengambil keputusan untuk siklus selanjutnya. Data penelitian berupa dokumentasi perencanaan, hasil observasi (pengamatan), dan hasil menulis. Instrumen pengumpul data utama adalah peneliti, sedangkan instrumen pununjangnya adalah RPP, Lembar observasi, dokumentasi, dan analisis hasil evaluasi. Hasil penelitian menunjukkan bahwa meningkatkan hasil belajar pada materi Laporan Keuangan, hal ini ditunjukkan adanya peningkatan yang mencapai KKM siklus I 52,17\% meningkat menjadi $91,30 \%$ pada siklus II.
\end{abstract}

Kata Kunci: hasil belajar; model stad; peserta didik

\section{Abstract}

Classroom Action Research (CAR) entitled "Improving Economic Learning Outcomes Using the STAD Model for Class XII IPS 4 Even Semester Students of SMA Negeri 1 Singkep for the Academic Year 2019 / 2020" is one of the efforts to improve the quality of education, especially increasing the value of students in understanding financial statements. This is done because many students consider accounting a difficult subject, so that in some accounting materials the number of students who reach the Minimum Completeness Criteria (KKM) is still low. The aim of this research is to improve the accounting learning outcomes of students in class XII Social Sciences 4 Even Semester SMA Negeri 1 Singkep by using the STAD model. This research was conducted at SMA Negeri I Singkep, Singkep District,

$\begin{array}{ll}\text { How to cite: } & \text { Putriasari, I. (2021) Meningkatkan Hasil Belajar Ekonomi Menggunakan Model STAD, Syntax Idea, } \\ & \text { 3(8), https://doi.org/10.36418/syntax-idea.v3i8.1430 } \\ \text { E-ISSN: } & \text { 2684-883X } \\ \text { Published by: } & \text { Ridwan Institute }\end{array}$


Lingga Regency, class XII IPS 4. The research was conducted in the second semester of the 2019/2020 school year. The research design used is an action research design with the following flow: making action plans, implementing actions in learning, observing the implementation of actions, and reflecting on the implementation of actions. The results of these reflections are used to make decisions for the next cycle. Research data in the form of planning documentation, results of observations (observations), and results of writing. The main data collection instrument is the researcher, while the supporting instruments are lesson plans, observation sheets, documentation, and analysis of evaluation results. The results showed that improving learning outcomes in the Financial Statements material, this was indicated by an increase which reached the KKM in the first cycle of $52.17 \%$ increased to $91.30 \%$ in the second cycle.

Keywords: learning outcome; stad model; students

\section{Pendahuluan}

Penguasaan peserta didik terhadap pelajaran akuntansi dapat dilihat dari hasil belajar yang diperoleh peserta didik setelah mengikuti proses pembelajaran akuntansi. Hasil yang diharapkan adalah hasil belajar akuntansi yang mencapai ketuntasan belajar peserta didik. Peserta didik dikatakan tuntas belajar akuntansi apabila nilai hasil belajar akuntasi peserta didik telah mencapai Kriteria Ketuntasan Minimum (KKM) yang ditetapkan sekolah (Rahayu, 2018).

Kenyataan tidak demikian, berdasarkan data yang dimiliki guru, pada materi sebelumnya jumlah peserta didik yang mencapai Kriteria Ketuntasan Minimum (KKM) XII IPS 4 adalah adalah 7 orang dari 23 orang peserta didik. Kriteria Ketuntasan Minimum (KKM) yang ditetapkan SMA Negeri I Singkep adalah 75.

Sebenarnya di dalam proses pembelajaran akuntansi ini tidaklah sulit hanya butuh pemahaman dari peserta didik namun peserta didik ini kurang fokus dalam belajar masih banyak yang kurang memperhatikan ketika guru menjelaskan dan ketika diskusi berlangsung peserta didik kurang serius masih banyak yang bermain. Guru sudah berusaha mengadakan perbaikan, baik dalam membuat persiapan mengajar maupun dalam proses pembelajaran yaitu dengan menerapkan pembelajaran kelompok dengan anggota masing-masing kelompok 5 atau 4 orang. Namun pembentukan anggota kelompok kemampuan akademisnya belum heterogen. Hal ini menyebabkan kelompok yang terbentuk kurang terkontrol (Mariyaningsih \& Hidayati, 2018).

Berdasarkan masalah-masalah di atas, perlu diantisipasi dengan mencari dan menerapkan metode pembelajaran yang dapat menumbuhkan kerjasama serta percaya diri peserta didik. Selain itu diperlukan metode atau model pembelajaran yang dapat membantu peserta didik dalam menyelesaikan masalah dalam pelajaran akuntansi. Sebagai salah satu alternatif peneliti tertarik untuk melakukan penelitian model STAD karena model pembelajaran ini sangat berperan dalam mengembangkan kerjasama serta percaya diri peserta didik. Penerapan pembelajaran ini memiliki keunggulan dimana peserta didik diajak untuk berperan serta dalam setiap proses pembelajaran. Pada proses pembelajaran ini peserta didik diberi kesempatan untuk berbagi informasi secara singkat 
dan teratur dalam bentuk diskusi kelompok. Kemudian peserta didik dalam kelompok dihadapkan dengan masalah yang harus diselesaikan bersama-sama dengan anggota kelompoknya. Dengan terbiasanya peserta didik dihadapkan dengan masalah akuntansi maka diharapkan bagi peserta didk untuk sensitif terhadap permasalahan serta mampu untuk menyelesaikan masalah tersebut. Oleh karena itu, dalam penelitian ini peneliti menggunakan pembelajaran model STAD untuk menciptakan proses pembelajaran yang lebih berpusat pada peserta didik dan mengembangkan kemampuan peserta didik demi meningkatkan hasil belajar akuntansi peserta didik (Zubaidah, 2016).

Bersamaan dengan pelaksanaan pembelajaran tersebut kami melakukan Penelitian Tindakan Kelas (PTK) dikelas XII IPS 4 tahun ajaran 2019/2020. Dalam pembelajaran ini, terdapat materi tentang laporan keuangan perusahaan dagang.

Sesuai dengan permasalahan di atas, adapun tujuan yang hendak dicapai dari penelitian ini adalah untuk mengetahui efektifitas pelaksanaan pembelajaran menggunakan model STAD dalam meningkatkan hasil belajar pada peserta didik kelas XII IPS 4 SMA Negeri I Singkep.

\section{Metode Penelitian}

Penelitian ini dilaksanakan di SMA Negeri 1 Singkep, Kecamatan Singkep Kabupaten Lingga kelas XII IPS 4. Penelitian dilakukan pada semester II tahun ajaran 2019/2020. Waktu penilitian tindakan kelas adalah 3 bulan, yaitu Januari 2020 sampai Maret 2020.

Subjek penelitian ini adalah peserta didik kelas XII IPS 4 SMA Negeri 1 Singkep tahun pelajaran 2019-2020 yang berjumlah 23 orang terdiri dari 13 putra dan 10 putri dengan kemampuan akademis yang heterogen. Adapun sasaran dari penelitian ini adalah untuk mengetahui efektifitas pelaksanaan pembelajaran menggunakan model STAD dalam meningkatkan hasil belajar pada peserta didik kelas XII IPS 4 SMA Negeri I Singkep.

Prosedur penelitian terdiri dari 4 tahap, yakni perencanaan, melakukan tindakan, observasi dan evaluasi. Refleksi pada setiap siklus akan berulang kembali pada siklussiklus berikutnya. Aspek yang diamati dalam setiap siklusnya adalah perilaku atau aktivitas siswa pada saat pemberian pembelajaran kimia terkait materi tentang kimia pokok bahasan Unsur Periode 3 dan Unsur Transisi Periode 4 dengan penerapan Model Pembelajaran Berbasis Inquiri (Hutagalung, 2021). Dengan mengamati perubahan perubahan perilaku siswa, peneliti dapat mengetahui tingkat kemajuan belajar siswa yang akan bepengaruh terhadap hasil belajarnya.Penelitian tindakan kelas ini terdiri dari 2 siklus, siklus I terdiri dari 2 kali pertemuan dan siklus kedua terdiri dari 2 pertemuan, satu pertemuan 90 menit.

Sumber data penelitian ini adalah peserta didik kelas XII IPS 4 SMA Negeri 1 Singkep tahun pelajaran 2019-2020 yang berjumlah 23 orang terdiri dari 13 putra dan 10 putri dengan kemampuan akademis yang heterogen. Teknik Pengumpulan Data dalam penelitian ini terdiri dari data pengamatan dan data hasil belajar. Data pengamatan diperoleh melalui lembar pengamatan. Pengamatan dilakukan terhadap 
aktivitas peserta didik selama proses pembelajaran untuk setiap kali pertemuan dengan mengisi lembar yang sudah disediakan. Data tentang hasil belajar peserta didik dikumpulkan melalui tes hasil belajar berupa ulangan harian pada materi laporan keuangan. Ulangan harian terdiri dari ulangan harian I dan ulangan harian II. Tes hasil belajar ini dilakukan untuk menilai keberhasilan dari tindakan. Adapun Teknik Analisis Data dalam Penelitian ini terdiri dari dua penerapan yaitu Analisis Data Tentang Aktivitas Guru dan Peserta Didik dan Analisis Keberhasilan Tindakan.

\section{Hasil dan Pembahasan}

\section{A. Hasil Penelitian}

\section{1) Pelaksanaan Tindakan}

\section{a) Tahap Persiapan}

Pada tahap ini peneliti menyiapkan instrumen penelitian yang terdiri dari perangkat pembelajaran dan instrumen pengumpul data. Perangkat pembelajaran terdiri dari rencana pelaksanaan pembelajaran (RPP) yang disusun untuk tiga kali pertemuan, lembar kerja peserta didik (LKPD) dan evaluasi untuk setiap kali pertemuan. Instrumen pengumpul data yang digunakan adalah lembar pengamatan dan seperangkat tes hasil belajar yang terdiri dari kisi-kisi penulisan soal tes dan naskah soal (Mutia, Budi, \& Serevina, 2014). Pada tahap ini juga ditetapkan kelas yang mengikuti pembelajaran melalui proses pembelajaran model STAD. Peserta didik dikelompokkan dengan anggota kelompok $4-5$ orang sehingga diperoleh 5 kelompok dengan 3 kelompok beranggotakan 5 orang dan 2 kelompok beranggotakan 4 orang. Kelompok dibentuk bersifat heterogen secara akademik dan jenis kelamin (Putra, Putra, \& RahayuEmisnawati, 2018).

\section{b) Tahap Pelaksanaan Proses Pembelajaran}

Proses pembelajaran dilaksanakan dua kali dalam satu minggu dengan waktu 4 jam pelajaran. Pelaksanaan proses pembelajaran pada penelitian ini menggunakan dua siklus terdiri atas 4 kali kali pertemuan dengan dua rencana pelaksanaan pembelajaran dan dua kali ujian harian.

\section{a. Siklus Pertama}

Siklus pertama dilakukan sebanyak 2 kali pertemuan dengan satu kali tes (ulangan harian 1).

1) Pertemuan Pertama (Rabu, 15 Januari 2020)

Pada pertemuan ini kegiatan pembelajaran membahas tentang Harga Pokok penjualan yang berpedoman pada RPP-1 dengan menggunakan LKPD-1 dan evaluasi-1. Sebelum pembelajaran dimulai guru memperkenalkan model pembelajaran yang akan diterapkan. Guru menjelaskan indikator ketercapaian dan mengkaitkan pengetahuan yang telah dimiliki peserta didik dengan materi yang akan dipelajari. Selanjutnya, guru mendemonstrasikan pengetahuan tentang Harga Pokok Penjualan dan dilanjutkan dengan mengorganisasikan peserta didik untuk 
duduk pada kelompok yang telah ditetapkan sebelumnya. Setelah memberikan LKPD peserta didik mengerjakannya bersama kelompoknya (Apendi, 2016).

Pada pertemuan ini terdapat kelompok yang tidak dapat berinteraksi dengan teman kelompoknya, membuat kelompok tersebut pasif. Setelah waktu mengerjakan LKPD berakhir, guru meminta peserta didik untuk mempresentasikan hasil kerjanya. Pertemuan ini ada dua kelompok yang mempresentasikan hasil kerjanya. Kemudian guru membimbing peserta didik untuk membahas hasil kerjanya. Di akhir proses pembelajaran guru membimbing peserta didik membuat kesimpulan tentang materi yang telah diajarkan dan memberikan evaluasi (Khoeriyatun Ni'mah, 2013).

2) Pertemuan Kedua (Jumat, 17Januari 2020)

Kegiatan pembelajaran pada pertemuan kedua berpandu pada RPP dengan menggunakan LKPD dan evaluasi. yakni membahas Laporan Laba/Rugi. Guru menjelaskan indikator ketercapaian dan mengingatkan peserta didik tentang laporan HPP yang telah dipelajari sebelumnya karena akan berkaitan dengan laporan laba rugi yang akan dibahas.

Selanjutnya, guru mendemonstrasikan pengetahuan tentang Laporan laba/rugi. Dengan berbekal data kertas kerja dan HPP, peserta didik dapat menyusun laporan laba rugi. Guru memberikan contoh soal yang berhubungan dengan penyusunan laporan laba rugi dan soal soal hitungan untuk mencari penjualan bersih, laba kotor dan laba bersih. Setelah demonstrasi, guru memberikan LKPD dan menginstruksikannya untuk dikerjakan secara individu terlebih dahulu, kemudian didiskusikan secara kelompok untuk menyatukan jawaban. Guru menegaskan kepada peserta didik bahwa jawaban LKPD yang dikerjakan peserta didik dan laporan kelompoknya agar dikumpulkan. Untuk meningkatkan pemahaman peserta didik tentang materi yang baru dibahas guru memberikan latihan soal. Diakhir pembelajaran, guru membimbing peserta didik menyimpulkan materi yang diajarkan dan memberi evaluasi.

Pada pertemuan kedua ini, masih ada peserta didik yang langsung berdiskusi dalam menyelesaikan LKPD dan tidak mengerjakannya secara individu terlebih dahulu (Santoso \& Suparman, 2017). Dalam diskusi kelompok maupun diskusi kelas masih ada peserta didik yang pasif tapi tidak sebanyak pada pertemuan pertama. Peserta didik sudah mulai terbiasa dengan pembelajaran pemecahan masalah dalam tipe STAD. Diharapkan pada pertemuan berikutnya guru mengingatkan kembali sebelum diskusi kelompok peserta didik terlebih dahulu berusaha mengerjakan LKPD dengan ide-idenya sendiri (Karimah, 2017).

\section{3) Pertemuan Ketiga (Rabu, 22 Januari 2020)}

Pada pertemuan ketiga ini guru mengadakan Ulangan Harian I yang memuat materi HPP dan laporan keuangan laba/ rugi 


\section{Refleksi siklus pertama:}

Berdasarkan lembar pengamatan, selama melakukan tindakan sebanyak dua kali pertemuan ada beberapa kekurangan-kekurangan yang dilakukan oleh guru dan peserta didik. Kekurangan-kekurangan tersebut diantaranya adalah sebagai berikut:

1) Pada pertemuan pertama guru kurang jelas dalam menyampaikan tata cara pelaksanaan pembelajaran sehingga pelaksanaan pembelajaran belum berjalan dengan baik.

2) Pada saat mengerjakan LKPD pada pertemuan pertama, peserta didik belum serius karena belum terbiasa dan belum dapat berdiskusi dengan baik dalam kelompoknya.

3) Pengawasan guru kurang merata, guru cenderung berada didepan kelas sehingga peserta didik yang lain merasa tidak diperhatikan.

4) Penggunaan waktu belum efektif, karena guru harus mengulang kembali materi sebelumnya.

Rencana yang dilakukan peneliti untuk memperbaiki tindakan adalah:

1) Menyampaikan tujuan dan tata cara pelaksanaan pembelajaran dengan lebih jelas sehingga proses pembelajaran dapat berjalan baik.

2) Memantau dan memberikan bimbingan yang lebih merata kesemua kelompok sehingga peserta didik mengetahui apa yang harus dikerjakan dan lebih serius dalam belajar.

3) Memberikan penjelasan betapa pentingnya kerjasama dalam kelompok sehingga dalam menyelesaikan suatu permasalahan peserta didik dapat lebih kreatif dan tidak hanya mengandalkan guru.

4) Mengatur waktu seefektif mungkin agar pelaksanan pembelajaran berikutnya dapat berjalan dengan baik.

\section{b. Siklus Kedua}

Siklus kedua dilakukan sebanyak dua kali pertemuan dengan satu kali tes (ulangan harian II). Pada siklus kedua ini peneliti masih tetap menerapkan langkah-langkah pembelajaran pada siklus pertama. Selanjutnya guru berusaha untuk mengulas kembali secara ringkas materi yang berkaitan dengan materi laporan keuangan. Kemudian memberikan lebih banyak tugas agar peserta didik lebih mahir dalam menyelesaikan laporan keuangan (Noviantii, Yuanita, \& Maimunah, 2020).

\section{1) Pertemuan Pertama (Rabu, 29 Januari 2020)}

Pertemuan pertama siklus kedua diawali dengan membahas secara ringkas Ujian Harian I. Kegiatan pembelajaran pada pertemuan pertama siklus kedua berpedoman pada RPP- dengan menggunakan LKPD dan evaluasi yaitu laporan perubahan modal. Guru menjelaskan indikator ketercapaian dan memotivasi Peserta didik dengan mengingatkan tentang laporan laba/ rugi. Guru mendemonstrasikan pengetahuan yang berhubungan dengan laporan perubahan modal. Dengan berbekal laporan 
laba/ rugi , peserta didik dapat menyusun laporan perubahan modal. Guru memberikan contoh soal dan membimbing peserta didik menyelesaiakn. Peserta didik duduk berkelompok dan guru memberikan LKPD, selanjutnya peserta didik mengerjakan LKPD secara kelompok. Selanjutnya LKPD yang telah dikerjakan dikumpulkan guru membimbing peserta didik melaksanakan diskusi kelas. Untuk memahirkan peserta didik, diberikan latihan kemudian dibahas bersama. Guru bersama peserta didik menyimpulkan materi yang dipelajari, selanjutnya guru memberikan evaluasi (Rahmawati, 2015).

Pada pertemaun ini, penerapan pembelajaran model STAD sudah berjalan dengan baik, tidak ada lagi peserta didik yang main-main dalam diskusi dan sebelum diskusi kelompok peserta didik terlebih dahulu bekerja sendiri dalam rangka menjawab soal.

\section{2) Pertemuan kedua ( Jumat, 31 Januari 2020)}

Pertemuan Kegiatan pembelajaran pada pertemuan kedua siklus kedua berpedoman pada RPP- dengan menggunakan LKPD dan evaluasi yaitu laporan neraca. Guru menjelaskan indikator ketercapaian dan memotivasi Peserta didik dengan mengingatkan tentang laporan laba/ rugi dan laporan perubahan modal. Guru mendemonstrasikan pengetahuan yang berhubungan dengan laporan neraca. Dengan berbekal laporan laba/ rugi dan laporan perubahan modal, peserta didik dapat menyusun laporan neraca. Guru memberikan contoh soal dan membimbing peserta didik menyelesaiakn. Selanjutnya LKPD yang telah dikerjakan dikumpulkan guru membimbing peserta didik melaksanakan diskusi kelas. Untuk memahirkan peserta didik, diberikan latihan kemudian dibahas bersama. Guru bersama peserta didik menyimpulkan materi yang dipelajari, selanjutnya guru memberikan evaluasi (Zuhra, 2020).

Pada pertemuan ini, penerapan pembelajaran model STAD sudah berjalan dengan baik, tidak ada lagi peserta didik yang main-main dalam diskusi dan sebelum diskusi kelompok peserta didik terlebih dahulu bekerja sendiri dalam rangka menjawab soal.

\section{3) Pertemuan Ketiga (Rabu, 5 Februari 2020)}

Pada pertemuan ketiga siklus kedua ini guru mengadakan ulangan harian II yang memuat materi laporan keuangan (laporan neraca) Ulangan harian II dilaksanakan selama dua jam pelajaran (90 menit).

\section{Refleksi siklus kedua:}

Pada siklus kedua sudah mulai lebih baik dari siklus pertama. Peserta didik sudah mulai mengerti dengan langkah-langkah pembelajaran, sehingga tidak terlalu banyak kesalahan yang dilakukan. Waktu yang tersedia sudah hampir sesuai dengan perencanaan. Dalam mengerjakan LKPD waktunya dibatasi sehingga waktu untuk berdiskusi kelas cukup. 
Untuk siklus kedua ini peneliti tidak melakukan perencanaan untuk siklus selanjutnya (Paloloang, 2014).

\section{2) Analisis Hasil Tindakan}

Data yang dikumpulkan pada penelitian ini adalah data aktivitas dan interaksi peserta didik dan guru serta kemajuan belajar peserta didik, suasana kelas selama proses pembelajaran, nilai perkembangan dan penghargaan kelompok, ketercapaian KKM hasil belajar akuntansi untuk setiap indikator dan keberhasilan tindakan.

\section{a. Aktivitas dan Interaksi Peserta didik dan Guru serta Kemajuan Belajar Peserta Didik}

Untuk mengetahui aktivitas dan interaksi peserta didik dan guru serta kemajuan belajar peserta didik dengan penerapan pembelajaran model STAD dilakukan pengamatan terhadap aktivitas dan interaksi peserta didik dan guru serta kemajuan belajar peserta didik selama pembelajaran berlangsung.

Pertemuan pertama, dari hasil pengamatan aktivitas dan interaksi peserta didik dan guru diperoleh bahwa guru dalam menjelaskan langkah-langkah pembelajaran belum jelas sehingga tidak dimengerti sepenuhnya oleh peserta didik. Dalam memberikan bimbingan guru cenderung berada didepan kelas. Masih ada beberapa peserta didik yang tidak memperhatikan penjelasan guru. Diskusi berjalan dengan lancar karena masing-masing peserta didik dapat bekerjasama dalam kelompoknya. Dalam hal kemajuan belajar peserta didik, beberapa peserta didik mau bertanya kepada teman dikelompoknya ataupun kepada guru jika mengalami hambatan. Hanya dua kelompok yang dapat menyelesaikan soal dengan baik. Dari hasil pengamatan pengamat menyarankan agar guru lebih jelas dalam menyampaikan tujuan dan tata cara pelaksanaan pembelajaran sehingga pembelajaran dapat berjalan dengan baik dan dapat memperhatikan peserta didik secara keseluruhan.

Pertemuan kedua, dari hasil pengamatan aktivitas dan interaksi peserta didik dan guru terlihat peserta didik mau mendengar penjelasan guru dengan baik namun masih ada beberapa peserta didik yang tidak memperhatikan guru. Dalam hal kemajuan belajar peserta didik, sebagian besar peserta didik telah memahami materi pelajaran yang diberikan dan peserta didik mau bertanya kepada kepada teman sekelompoknya ataupun kepada guru dalam menyelesaikan soal serta dapat menjawab pertanyaan yang diberikan guru dengan baik. Ada empat kelompok yang dapat mempresentasikan hasil diskusi.

Dari hasil pengamatan pengamat menyarankan agar guru selalu mengawasi peserta didik dalam belajar di kelompoknya sehingga peserta didik dapat lebih serius dan lebih aktif, salain itu guru diharapkan lebih menguasai kelas sehingga dapat mengendalikan seluruh kegiatan peserta didik.

Pertemuan keempat, berdasarkan hasil pengamatan terlihat aktivitas peserta didik dalam kelompok sangat baik, masing-masing peserta didik mau berusaha untuk berfikir terlebih dahulu, mendiskusikan soal dengan 
kelompoknya dan bertanggung jawab terhadap anggota kelompoknya, jika ada yang benar-benar mereka tidak mengerti baru bertanya pada guru. Kemajuan belajar peserta didik terlihat sangat baik ditandai dengan masing-masing peserta didk dalam kelompok mampu menyelesaikan soal dengan baik dan benar. Peserta didik dengan semangat mempresentasikan hasil kerjanya didepan kelas. Secara keseluruhan penerapan pembelajaran model STAD berjalan dengan lancar karena peserta didik mengikuti proses pembelajaran dengan baik.

Pertemuan kelima, berdasarkan hasil pengamatan terlihat aktivitas peserta didik dalam kelompok sangat lebih baik, masing-masing peserta didik mau berusaha untuk berfikir terlebih dahulu, seluruh kelompok mendiskusikan soal dengan kelompoknya dan bertanggung jawab terhadap anggota kelompoknya, jika ada yang benar-benar mereka tidak mengerti baru teman teman sekelompoknya berusaha membantu teman yang masih belum mengerti. Kemajuan belajar peserta didik terlihat sangat baik ditandai dengan masingmasing peserta didk dalam kelompok mampu menyelesaikan soal dengan baik dan benar. Peserta didik dengan semangat mempresentasikan hasil kerjanya didepan kelas. Secara keseluruhan penerapan pembelajaran model STAD berjalan dengan sangat hampir mendekati kesempurnaan karena peserta didik mengikuti proses pembelajaran dengan baik.

\section{b. Nilai Perkembangan dan Penghargaan Kelompok}

Berdasarkan data skor dasar, skor ulangan harian 1 dan skor ulangan harian 2 dapat dilihat nilai perkembangan tiap anggota kelompok. Nilai perkembangan anggota kelompok diperoleh dari selisih skor dasar dengan skor tes hasil belajar. Nilai perkembangan peserta didik pada siklus I diperoleh dari selisih skor dasar dengan skor ulangan harian I. Nilai perkembangan peserta didk pada siklus II diperoleh dari selisih skor ulangan harian I (skor dasar) dengan skor ulangan harian I. Pada penelitian ini pembentukan kelompok terjadi dua kali. Penyusunan kelompok siklus I dan siklus II berturut-turut berdasarkan nilai skor dasar dan ulangan harian I. Nilai perkembangan peserta didik pada siklus I dan II disajikan pada tabel berikut ini.

Tabel 1

Nilai Perkembangan Peserta Didik pada Siklus I dan Siklus II

\begin{tabular}{ccccc}
\hline \multirow{2}{*}{$\begin{array}{c}\text { Nilai } \\
\text { perkembangan }\end{array}$} & \multicolumn{2}{c}{ Siklus I } & \multicolumn{2}{c}{ Siklus II } \\
\cline { 2 - 5 } & Jumlah & $\mathbf{\%}$ & Jumlah & \% \\
\hline 5 & 3 & 13.04 & 2 & 4.69 \\
\hline 10 & 2 & 8.69 & 4 & 17.39 \\
\hline 20 & 6 & 26.08 & 7 & 30.43 \\
\hline 30 & 12 & 52.17 & 10 & 43.47 \\
\hline
\end{tabular}

Persentase peserta didik yang menyumbangkan nilai perkembangan 30 pada siklus pertama lebih banyak dibandingkan siklus kedua. Skor dasar yang 
digunakan untuk pembentukan kelompok siklus kedua lebih tinggi dari pada skor dasar pembentukan kelompok siklus pertama. Hal ini menunjukkan bahwa terjadi penurunan nilai perkembangan kelompok. Hal ini terjadi karena skor dasar (hasil belajar peserta didik sebelum tindakan) rendah, sehingga nilai perkembangan pada siklus pertama tinggi. Selanjutnya nilai ulangan harian I menjadi skor dasar pada siklus kedua dengan hasil yang lebih baik sehingga peningkatan nilai perkembangan siswa tidak setinggi pada siklus pertama. Penurunan nilai perkembangan juga disebabkan oleh tingkat kesulitan materi pelajaran.

Setelah diperoleh nilai perkembangan individu yang akan disumbangkan kepada kelompok, kemudian dicari rata-rata nilai perkembangan itu dan disesuaikan dengan kriteria penghargaan kelompok sehingga diperoleh penghargaan masing-masing kelompok. Penghargaan yang diperoleh oleh masing-masing kelompok pada siklus I dan siklus II dapat dilihat pada tabel berikut.

Tabel 2

Penghargaan yang Diperoleh Masing-Masing Kelompok Pada Siklus I dan Siklus II

\begin{tabular}{ccccc}
\hline \multirow{2}{*}{$\begin{array}{c}\text { Nama } \\
\text { kelompok }\end{array}$} & \multicolumn{2}{c}{ Siklus I } & \multicolumn{2}{c}{ Siklus II } \\
\cline { 2 - 5 } & Skor kelompok & Penghargaan & Skor kelompok & Penghargaan \\
\hline I & 27.5 & Super & 22.5 & Super \\
\hline II & 21 & Hebat & 24 & Super \\
\hline III & 25 & Super & 27.5 & Super \\
\hline IV & 26 & Super & 21 & Hebat \\
\hline V & 20 & Hebat & 30 & Super \\
\hline
\end{tabular}

\section{c. Ketuntasan Hasil Belajar akuntansi (Ketercapaian Kompetensi Dasar)}

Berdasarkan skor yang diperoleh peserta didik untuk setiap indikator pada ulangan blok I dan ulangan blok II yang diperolah peserta didik dapat dinyatakan dengan jumlah peserta didik yang mencapai KKM seperti pada tabel.

Tabel 3

Ketercapaian KKM Pada Ulangan Harian I

\begin{tabular}{lccc}
\hline \multirow{2}{*}{ No } & Indikator & $\begin{array}{c}\text { Jumlah Peserta } \\
\text { Didik Mencapai } \\
\text { KKM }\end{array}$ & Persentase \\
\hline 1 & Menyusun HPP dan laporan laba /rugi & 12 & $52.17 \%$ \\
\hline
\end{tabular}

Dari tabel di atas ketercapaian kompetensi dasar dapat dideskripsikan sebagai berikut:

Siklus 1 : Banyak peserta didik yang mencapai KKM $\geq 75$ adalah 12 orang atau $52,17, \%$ dari jumlah peserta didik. Hal ini berarti untuk indikator 
"menyusun laporan laba / rugi dan laporan perubahan modal" terdapat peserta didik yang tidak mencapai KKM 11 orang. Kesalahan yang banyak terjadi dalam menyelesaikan soal yang berhubungan dengan indikator ini adalah peserta didik kurang teliti dalam menghitung laporan laba rugi sehingga menyebabkan laporan perubahan modalnya juga salah.

\section{Tabel 4}

Ketercapaian KKM Pada Ulangan Harian II

\begin{tabular}{cccc}
\hline No & Indikator & $\begin{array}{c}\text { Jumlah Siswa } \\
\text { Mencapai KKM }\end{array}$ & Persentase \\
\hline 1 & $\begin{array}{l}\text { Menyusun laporan perubahan modal dan } \\
\text { laporan neraca }\end{array}$ & 21 & $91,30 \%$ \\
\hline
\end{tabular}

Kesimpulan yang dapat diambil dari tabel ketercapaian pada ulangan harian II diatas adalah:

Siklus II : Banyak peserta didik yang mencapai KKM $\geq 75$ adalah 21 orang dari jumlah peserta didk 23. Hal ini berarti untuk indikator Menyusun laporan neraca hanya 2 orang peserta didik saja yang belum mencapai standar ketuntasan.

Untuk mengetahui peningkatan hasil belajar peserta didik dapat dilihat tabel berikut:

Tabel 5

Daftar Distribusi Frekuensi Skor Hasil Belajar

\begin{tabular}{cccc}
\hline \multirow{2}{*}{ Interval } & Skor Dasar & Ulangan Harian I & Ulangan Harian II \\
\cline { 2 - 4 } & Banyak Siswa & Banyak Siswa & Banyak Siswa \\
\hline $10-14$ & 0 & 0 & 0 \\
$15-19$ & 1 & 0 & 0 \\
$20-24$ & 1 & 0 & 0 \\
$25-29$ & 0 & 0 & 0 \\
$30-34$ & 1 & 0 & 0 \\
$35-39$ & 0 & 0 & 0 \\
$40-44$ & 2 & 0 & 0 \\
$45-49$ & 1 & 1 & 0 \\
$50-54$ & 3 & 0 & 0 \\
$55-59$ & 1 & 4 & 1 \\
$60-64$ & 1 & 3 & 0 \\
$65-69$ & 2 & 3 & 1 \\
$70-74$ & 1 & 0 & 0 \\
$75-79$ & 3 & 7 & 7 \\
$80-84$ & 2 & 2 & 3 \\
$85-89$ & 2 & 0 & 2 \\
$90-94$ & 1 & 2 & 5 \\
$95-100$ & 1 & 1 & 23 \\
\hline$\sum f$ & 23 & 23 & \\
\hline
\end{tabular}




\section{B. Pembahasan}

Berdasarkan pengamatan peneliti, terlihat peserta didik lebih bersemangat dalam belajar dan lebih aktif dalam proses pembelajaran. Dari uraian diatas dapat disimpulkan bahwa frekuensi peserta didik yang mencapai KKM pada UH I dan UH II lebih banyak dari pada skor dasar. Sedangkan untuk frekuensi peserta didik yang mencapai KKM untuk UH II lebih banyak dari UH I. Dengan demikian dapat disimpulkan bahwa adanya perubahan hasil belajar peserta didik ke arah yang lebih baik, sehingga penerapan pembelajaran model STAD dapat meningkatkan hasil belajar peserta didik di kelas XII IPS 4 SMA Negeri 1 Singkep.

\section{Kesimpulan}

Berdasarkan hasil penelitian dan pembahasan diperoleh kesimpulan bahwa dengan pelaksanaan pembelajaran model STAD pada UH I terdapat 12 peserta didik dari 23 peserta didik yang mencapai KKM. Pada UH II terdapat 21 peserta didik yang mencapai KKM. Selanjutnya dengan melihat perbandingan skor hasil belajar akuntansi peserta didik melalui pembelajaran model STAD siklus I 52,17\% dan siklus II 91,30\% hasilnya lebih meningkat dari skor dasar. Hal ini berarti penerapan pembelajaran pembelajaran model STAD dapat meningkatkan hasil belajar peserta didik mengenai materi laporan keuangan perusahaan dagang. Dengan demikian peneliti menyimpulkan bahwa penerapan pembelajaran model STAD dapat meningkatkan hasil belajar peserta didik pada materi Laporan Keuangan. 
Irda Putriasari

\section{BIBLIOGRAFI}

Apendi, Tedi. (2016). Penerapan Model Pembelajaran Learning Cycle 7e (Elicit, Engage, Explore, Explain, Elaborate, Evaluate, And Extend) Untuk Meningkatkan Kemampuan Koneksi Matematis Siswa Smk. Fkip Unpas.Google Scholar

Hutagalung, Tama Ristauli. (2021). Upaya Meningkatkan Hasil Belajar Indahnya Keragaman Budaya Negeriku Melalui Model Pembelajaran Gal'perin Di Kelas IvB Sd Negeri 152979 Pandan I Tp 2019/2020. Jurnal Estupro, 6(2), 9-21. Google Scholar

Karimah, Sayyidatul. (2017). Pembelajaran kooperatif tipe STAD (Student Team Achievement Division) dalam meningkatkan aktivitas dan hasil belajar. Delta: Jurnal Ilmiah Pendidikan Matematika, 1(1), 70-81. Google Scholar

Khoeriyatun Ni'mah, Pristiani. (2013). Upaya Meningkatkan Prestasi Belajar Peserta Didik Melalui Model Pembelajaran Problem Based Instruction Materi Keliling dan Luas Lingkaran Kelas VIII Semester Genap MTs Uswatun Hasanah Mangkang Tahun Pelajaran 2011/2012. IAIN Walisongo. Google Scholar

Mariyaningsih, Nining, \& Hidayati, Mistina. (2018). Bukan Kelas Biasa: Teori dan Praktik Berbagai Model dan Metode Pembelajaran Menerapkan Inovasi Pembelajaran di Kelas-Kelas Inspiratif. CV Kekata Group. Google Scholar

Mutia, Mutia, Budi, Agus Setyo, \& Serevina, Vina. (2014). Pengembangan Perangkat Pembelajaran Fisika Sma Berbasis Problem Based Learning Sebagai Implementasi Scientific Approach Dan Penilaian Authentic. Prosiding Seminar Nasional Fisika (E-Journal), 3, 169-184. Google Scholar

Noviantii, Erna, Yuanita, Putri, \& Maimunah, Maimunah. (2020). Pembelajaran berbasis masalah dalam meningkatkan kemampuan pemecahan masalah matematika. Journal of Education and Learning Mathematics Research (JELMaR), 1(1), 65-73. Google Scholar

Paloloang, Muhammad Fachri Baharuddin. (2014). Penerapan model problem based learning (PBL) untuk meningkatkan hasil belajar siswa pada materi panjang garis singgung persekutuan dua lingkaran di kelas VIII SMP Negeri 19 Palu. Jurnal Elektronik Pendidikan Matematika Tadulako, 2(1), 67-77.

Putra, Randi Eka, Putra, Ade Marta, \& Emisnawati, Emisnawati. (2018). Meningkatkan Proses Belajar Siswa Pada Mata Pelajaran Pendidikan Jasmani Dengan Materi Passing Bawah Bola Voli Mini Melalui Pembelajaran Kooperatif Model Stad Pada Siswa Kelas V Sd Negeri 168/Ii Sumber Mulya Kabupaten Bungo. Jurnal Muara Olahraga, 1(1), 87-97. Google Scholar

Rahayu, Mesy. (2018). Peningkatan Hasil Belajar dan Keaktifan Siswa Dalam Pembelajaran Akuntansi Materi Jurnal Umum Melalui Model Pembelajaran Kooperatif Tipe NHT Pada Siswa XII IPS 1 SMAN 4 Penajam Paser Utara. Jurnal 
Ilmiah Pendidikan Humaniora, 4(5), 659-672. Google Scholar

Rahmawati, Maila Husnaya Zulfa. (2015). Upaya meningkatkan hasil belajar peserta didik melalui metode word square pada pembelajaran tematik tema kesehatan kelas I MI Al Islam Mijen Demak tahun ajaran 2014/2015. UIN Walisongo. Google Scholar

Santoso, Bimo Budi, \& Suparman, Achmad Rante. (2017). Pengaruh model pembelajaran inkuiri terbimbing terhadap hasil belajar kognitif peserta didik di SMA Negeri 01 Manokwari (Studi pada pokok bahasan kelarutan dan hasil kali kelarutan). Jurnal Nalar Pendidikan, 5(1), 21-30. Google Scholar

Zubaidah, Siti. (2016). Keterampilan abad ke-21: Keterampilan yang diajarkan melalui pembelajaran. Seminar Nasional Pendidikan, 2(2), 1-17. Google Scholar

Zuhra, Cut Hayaton. (2020). Peningkatan Hasil Belajar Ekonomi melalui Model Pembelajaran Project Based Learning Materi Siklus Akuntansi pada Perusahaan Dagang. Jurnal Kinerja Kependidikan (JKK), 2(4), 704-721. Google Scholar

\section{Copyright holder:}

Irda Putriasari (2021)

First publication right:

Syntax Idea

This article is licensed under:

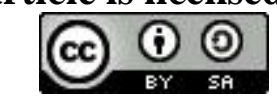

